\title{
DOES GLOBALIZATION DEGRADE OUR ENVIRONMENT? AN EMPIRICAL INVESTIGATION IN BANGLADESH
}

\author{
Gazi Mohammed Mahbub ${ }^{1}$, S. M. Nasir Uddin², Saddam Hossain ${ }^{3}$, Khaleda Akter ${ }^{4}$ \\ 1\&2. Lecturer, Department of Economics, Bangabandhu Sheikh Mujibur Rahman Science and Technology \\ University, Gopalganj-8100, Bangladesh. \\ ${ }^{3 .}$ M. Sc., Department of Economics, Jahangirnagar University, Savar, Bangladesh. \\ 4. Lecturer, Department of Economics, Pabna University of Science and Technology, Pabna, Bangladesh.
}

DOI: 10.46609/IJSSER.2020.v05i09.002 URL: https://doi.org/10.46609/IJSSER.2020.v05i09.002

\begin{abstract}
The unification process of the national economies to the global circumference, termed as globalization, is increasing day by day that accelerates economic activities within an economy by enhancing not only domestic and foreign investment but also mobilizing capital and labor across economies. Upward pressure on energy was created by the globalization induced economic activities that leads to fossil fuels' energy consumption. As a consequence, the concentration of carbon dioxide $(\mathrm{CO} 2)$ gas is increasing into the atmosphere- the most noticeable element responsible for raising the average temperature of the earth. It is the channel through which globalization can degrade our environment. This study is an empirical attempt to test this channel in the context of Bangladesh by using annual data from 1973 to 2013. ARDL bounds test results provide the confirmation of cointegration among $\mathrm{CO} 2$ emissions, economic growth, and globalization. Empirical findings reveal that although globalization degrades the environmental quality in Bangladesh, the long-run emission elasticity is smaller than the short-run elasticity, which implies that the globalization induced emissions will decline gradually.
\end{abstract}

Keywords: Globalization; economic growth; $\mathrm{CO} 2$ emissions; Bangladesh; ARDL bounds test.

\section{Introduction}

Over the last 100 years, the average temperature of the globe has been increased gradually, which is a credible threat to the existence of modern human civilization on earth. This rising temperature, termed as global warming, becomes a discussable burning issue in the international circumference in recent decades. Some countries like Bangladesh, Maldives, etc. are in great danger. Global warming contributes to break and melt ice in the Antarctic region. As a result, the 


\section{International Journal of Social Science and Economic Research}

ISSN: $2455-8834$

Volume:05, Issue:09 "September 2020"

sea level is rising alarmingly. Many coastal regions will be undergone below seawater as a consequence. Therefore, it's necessary to stop raising the average temperature of the earth by taking some urgent and excellent policies. Emissions of Greenhouse gas (GHG) are the main contributors to global warming, and among the GHG the carbon dioxide (CO2) along is the dominant player that is responsible for raising the temperature of the atmosphere. The more $\mathrm{CO} 2$ will be emitted into the atmosphere the greater will be global warming. So, the reduction policy of $\mathrm{CO} 2$ emissions will be the best strategy. But it is not so easy to reduce $\mathrm{CO} 2$ emissions in the blink of an eye. At first, we have to identify the core determinants of the $\mathrm{CO} 2$ emissions, and then we have to make a policy to find out the alternative path to control that determinant. On this background, an attempt to analyze the globalization effect on the environment is taken by this study, and we take Bangladesh as the study country.

The term globalization refers unification process of the national economies to the global circumference. One country is now more interlinked with another country or with a global market than before. This unification increases the volume of trade, investment, and volume of production that fosters economic growth. Many researchers found strong evidence on the nexus between globalization and economic growth (e.g., see (Dreher, 2003; Afzal, 2007; Ullah et al., 2013; Samimi\&Jenatabadi, 2014; Ying et al., 2014; Gurgul\&Lach, 2014; Zahonogo, 2018)). More openness (globalized) of a country indicates more economic activities, which lead to more domestic investment, more foreign investment, bulk production and industrialization, rapid urbanization, and more fossil fuels energy consumption into that country. These globalization induced economic activities also lead to emissions of GHG into the atmosphere. Many researchers found a positive association between the initial economic growth of a country and environmental degradation (see Saboori et al. 2012; AdebolaSolarin et al. 2017; Rayhan et al., 2018; Akadiri et al. 2019; Zafar et al. 2019). So, by summing up we find that globalization contributes to economic growth and economic growth at the initial level of development impedes environmental quality. Therefore, we can deduce that globalization is responsible for the environmental degradation of a country when it experiences an initial level of economic development. This is the theoretical channel by which globalization can inversely affect environmental quality. Many researchers used CO2 emissions to represent environmental degradation (Ang, 2007; Pao et al., 2011; Saboori\&Sulaiman, 2013; Farhani et al., 2014; Rayhan\& Islam, 2015; Rayhan\& Islam, 2018; Rayhan et al., 2018; Rafindadi\& Usman, 2019, Suki et al., 2020) so that this study also includes CO2 emissions as the dependent variable to represent the quality of the environment.

Bangladesh is a young developing country, experiencing an excellent growth rate in recent decades (Daily Star, 2019). The increasing openness (degree of globalization) of this country leads to increasing domestic and foreign investment, significant industrialization and urbanization, increasing fossil fuel energy consumption, and bulk production. These also lead to 


\section{International Journal of Social Science and Economic Research}

ISSN: $2455-8834$

Volume:05, Issue:09 "September 2020"

increasing $\mathrm{CO} 2$ emissions into the atmosphere. Per capita, $\mathrm{CO} 2$ emissions have been increased from 0.067 metric tons to 0.533 metrics tons for 1973 to 2016 (World Development Indicator (WDI), 2020). The degree of globalization also increases at the same time-increase from 19.1 to 51.4 for 1973 to 2013 (KOF globalization index of Dreher (2006), and Savina et al. (2019)).

\section{Literature Review}

Some previous studies that found a positive association between globalization and environmental degradation are discussed in this section. Shahbaz et al. (2015) studied India from 1970 to 2012 and found that globalization can impede the quality of the environment. A study by Shahbaz et al. (2016) found that globalization increased CO2 emissions in Morocco, Sudan, Ghana, Tanzania, and South Africa. Shahbaz et al. (2018) examined the annual data of Japan from 1970 to 2014 and conclude that globalization increased the concentration of $\mathrm{CO} 2$ into the atmosphere. Khan \&Ullah (2019) examine the annual data of Pakistan for 1975-2014 and found that emissions elasticity for economic globalization was 0.38 , for political globalization 0.19 , and social globalization, it was 0.11. Moreover, Studies of Akadiri et al. (2019), Rafindadi\& Usman (2019), and Salahuddin et al. (2019) also found that globalization was responsible for increasing concentration of CO2 into the air. A recent study of Suki et al. (2020) reported that globalization caused to degrade the quality of the environment in Malaysia in the long-run. From these studies, we can conclude that globalization can degrade environmental quality.

Moreover, many studies (Shahbaz, Solarin, et al., 2016; Shahbaz, Khan, et al., 2016; Zafar et al., 2019; Rahman, 2020; Saud et al., 2020) found that globalization improves environmental quality. Shahbaz, Solarin, et al. (2016) found for Tunisia, Angola, Libya, Kenya, Cameroon, Egypt, and Congo Republic; Shahbaz, Khan, et al. (2016) found for China; Zafar et al. (2019) found for OECD countries; Rahman (2020) found for USA, UK, South Korea, India, Germany, Canada, Brazil, France, Japan, and China; and Saud et al. (2020) found for one-belt-one-road initiative countries that globalization improved the quality of the environment. So, a mix of findings exists in the literature.

\section{Methodology}

This study used $\mathrm{CO} 2$ emissions per capita (denoted as $\mathrm{CO} 2$ in this study) to represent environmental degradation, per capita real GDP (as PRGDP) for economic growth, and globalization index (as GI) to represent globalization. The logarithmic transformation of the variables used to get elasticities here. Data of CO2 and PRGDP have taken from WDI, and the data of GI has taken from the KOF globalization index (Dreher, 2006; Savina et al., 2019). The range of data is 1973-2013. 


\section{International Journal of Social Science and Economic Research}

ISSN: $2455-8834$

Volume:05, Issue:09 "September 2020"

We devoted the autoregressive distributed lag (ARDL) bounds test to screen the cointegration status among the LNCO2, LNPRGDP, and LNGI. Pesaran et al. (2001) developed this test, which is exercisable if all the series are found $\mathrm{I}(0)$, or all the series are $\mathrm{I}(1)$, or admixture of $\mathrm{I}(1)$ and $\mathrm{I}(0)$, but it is not applicable if any one of the series becomes $\mathrm{I}(2)$. Therefore, there exists a precondition for this estimation, which demand to identify the order of LNCO2, LNPRGDP, and LNGI. In order to fulfill that precondition the Augmented Dickey-Fuller (ADF) test has been assigned (which is developed by Dickey and Fuller $(1978,1971)$ ). When neither of the series finds I(2), the ARDL bounds test approach has been performed and its equations looks like as follows:

$$
\begin{aligned}
& \Delta L N C O 2_{t}=\alpha_{1}+\alpha_{2} t+\alpha_{3} L_{N C O 2_{t-1}}+\alpha_{4} L N P R G D P_{t-1}+\alpha_{5} L N G I_{t-1}+ \\
& \sum_{i=1}^{j} \beta_{1 i} \Delta L N C O 2_{t-i}+\sum_{i=0}^{k} \beta_{2 i} \Delta L N P R G D P_{t-i}+\sum_{i=0}^{l} \beta_{3 i} \Delta L N G I_{t-i}+u_{i t}
\end{aligned}
$$

This test has 2 sets of table values (Pesaran et al., 2001); one is called upper bound value and another one is called lower bound value. The estimated F-statistic should exceed the upper bound value of the Pesaran et al. (2001) value sets for confirming the cointegration. An estimated value that lies between the upper and lower bound values, or that lies below the lower bound value, does not confirm the cointegration. Therefore, the estimated F-value of the model should exceed the upper bound value for confirming the long-run equilibrium association among LNCO2, LNPRGDP, and LNGI. After the confirmation of the long-run association the error correction model can be estimated by using the following equation:

$$
\Delta L N C O 2_{t}=\sum_{i=1}^{j} \beta_{1 i} \Delta L N C O 2_{t-i}+\sum_{i=0}^{k} \beta_{2 i} \Delta L n P R G D P_{t-i}+\sum_{i=0}^{l} \beta_{3 i} \Delta L n G I_{t-i}+\lambda E C T_{t-1}+\alpha_{1}+\alpha_{2} t+\varepsilon_{t}
$$

Some diagnostic tests are also be performed for getting stable, reliable, consistent, and efficient estimators.

\section{Results and Discussions}

The Time-series plot of the variables under this study (LNCO2, LNPRGDP, and LNGI) have illustrated in Figure-1, and an increasing trend has been observed for each of the series. The visual illustration indicates an association among these series. However, we use rigorous statistical tools for checking cointegration in this study. In the beginning, it is crucial to identify the order of LNCO2, LNPRGDP, and LNGI. We have performed the ADF test for checking stationarity status (results are in Table 1). 
For 'with constant' specification LNCO2, LNPRGDP and LNGI are found non-stationary at the level form (as the respective $\mathrm{p}>0.05$ ) but are found stationary at their first difference form (as the respective $\mathrm{p}<0.05)$. These findings imply that the variables LNCO2, LNPRGDP, and LNGI are $\mathrm{I}(1)$.

For 'with constant \& trend' specification LNCO2 is found stationary for both levels and at first difference form (as the respective $\mathrm{p}<0.05$ ), which implies that LNCO2 is $\mathrm{I}(0)$. The other two variables LNPRGDP and LNGI are found non-stationary at the level form (as the respective $\mathrm{p}>0.05$ ) but are found stationary at their first difference form (as the respective $\mathrm{p}<0.05$ ), which imply that LNPRGDP and LNGI are I(1) too.

\section{Figure 1. Pattern of LNCO2, LNPRGDP and LNGI}
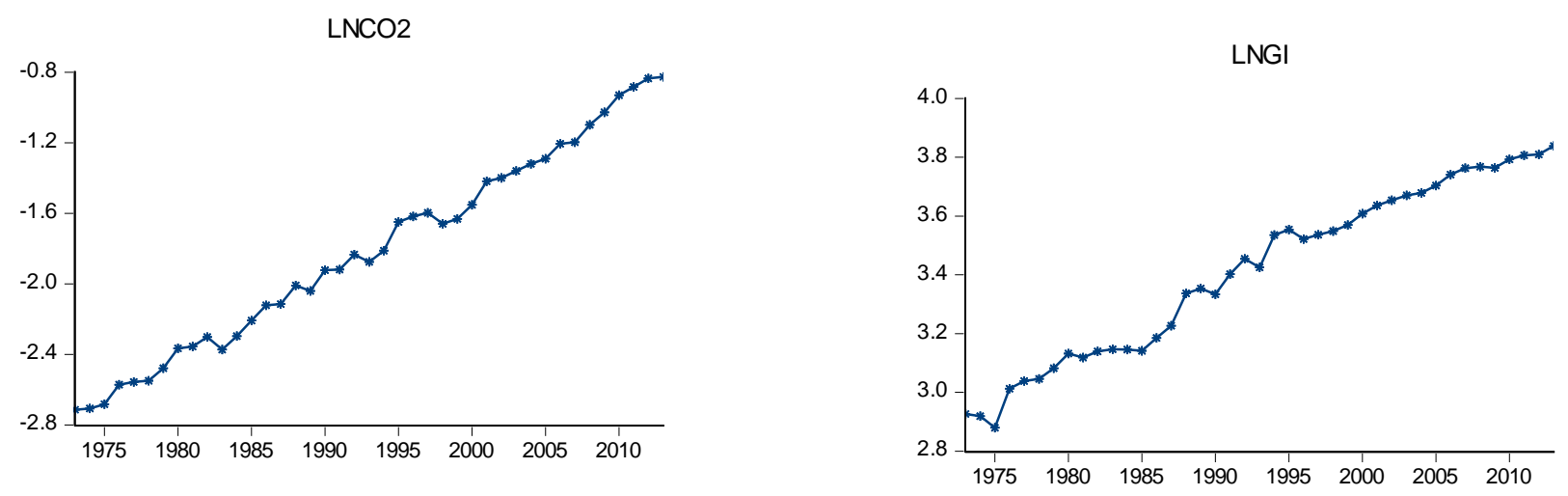

LNPRGDP

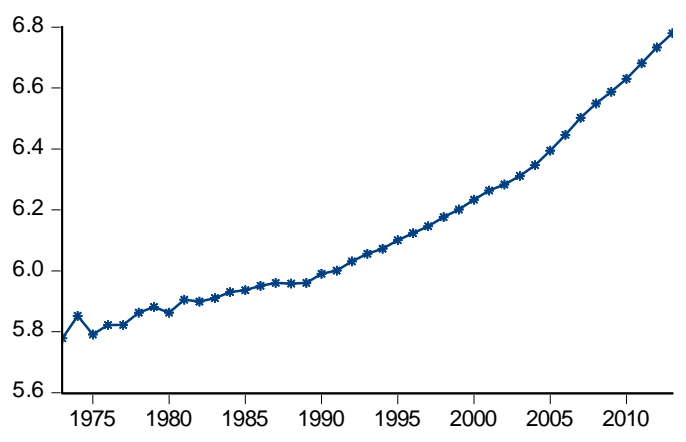


International Journal of Social Science and Economic Research

ISSN: 2455-8834

Volume:05, Issue:09 "September 2020"

Table 1. Stationarity test results of LNCO2, LNPRGDP and LNGI

\begin{tabular}{|c|c|c|c|c|}
\hline Variables at level form & & & & \\
\hline & & $\mathrm{LNCO} 2$ & LNPRGDP & LNGI \\
\hline With Constant & t-Statistic & 1.2283 & 3.8119 & -0.8317 \\
\hline & Prob. & 0.9977 & 1.0000 & 0.7990 \\
\hline & & & & \\
\hline With Constant \& Trend & t-Statistic & -4.0446 & 0.4950 & -2.6362 \\
\hline & Prob. & 0.0149 & 0.9989 & 0.2673 \\
\hline & & & n0 & \\
\hline & & $* * *$ & n0 & n0 \\
\hline & ariables at fi & difference & & \\
\hline & & $\mathrm{d}(\mathrm{LNCO} 2$ & $\mathrm{d}($ LNPRGD & $\mathrm{d}(\mathrm{LNGI}$ \\
\hline With Constant & t-Statistic & -6.5040 & -6.4696 & -7.3873 \\
\hline & Prob. & $\begin{array}{l}0.0000 \\
* * *\end{array}$ & $\begin{array}{l}0.0000 \\
* * *\end{array}$ & $\begin{array}{l}\mathbf{0 . 0 0 0 0} \\
* * *\end{array}$ \\
\hline With Constant \& Trend & $\mathrm{t}$-Statistic & -6.6698 & -13.3135 & -7.5438 \\
\hline & Prob. & $\begin{array}{l}\mathbf{0 . 0 0 0 0} \\
* * *\end{array}$ & $\begin{array}{l}0.0000 \\
* * *\end{array}$ & $\begin{array}{l}\mathbf{0 . 0 0 0 0} \\
* * *\end{array}$ \\
\hline & & & (Source: Au & tor's calct \\
\hline
\end{tabular}

Table 2. Details of Optimal lag selection by VAR

\begin{tabular}{lllllll}
\hline \multicolumn{6}{c}{ "Endogenous variables: D(LNCO2) D(LNPRGDP) D(LNGI) and Exogenous variables: C" } \\
\hline Lag & LogL & LR & FPE & AIC & SC & HQ \\
0 & 226.9453 & NA & $7.93 \mathrm{e}-10$ & -12.44141 & $-12.30945^{*}$ & $-12.39535^{*}$ \\
1 & 234.4157 & 13.28072 & $8.66 \mathrm{e}-10$ & -12.35643 & -11.82859 & -12.17220 \\
2 & 242.9105 & 13.68606 & $9.02 \mathrm{e}-10$ & -12.32836 & -11.40464 & -12.00596 \\
3 & 258.7043 & $22.81321 *$ & $6.37 \mathrm{e}-10^{*}$ & $-12.70579^{*}$ & -11.38619 & -12.24522 \\
4 & 266.9515 & 10.53804 & $7.03 \mathrm{e}-10$ & -12.66397 & -10.94849 & -12.06522
\end{tabular}

*indicates lag order selected by the criterion, where "HQ: Hannan-Quinn information criterion, AIC: Akaike information criterion, LR: sequential modified LR test statistic, SC: Schwarz information criterion, FPE: Final prediction error" (Source: Author's calculation) 
International Journal of Social Science and Economic Research

ISSN: 2455-8834

Volume:05, Issue:09 "September 2020"

Figure 2. Top 20 models based on AIC with lag 3

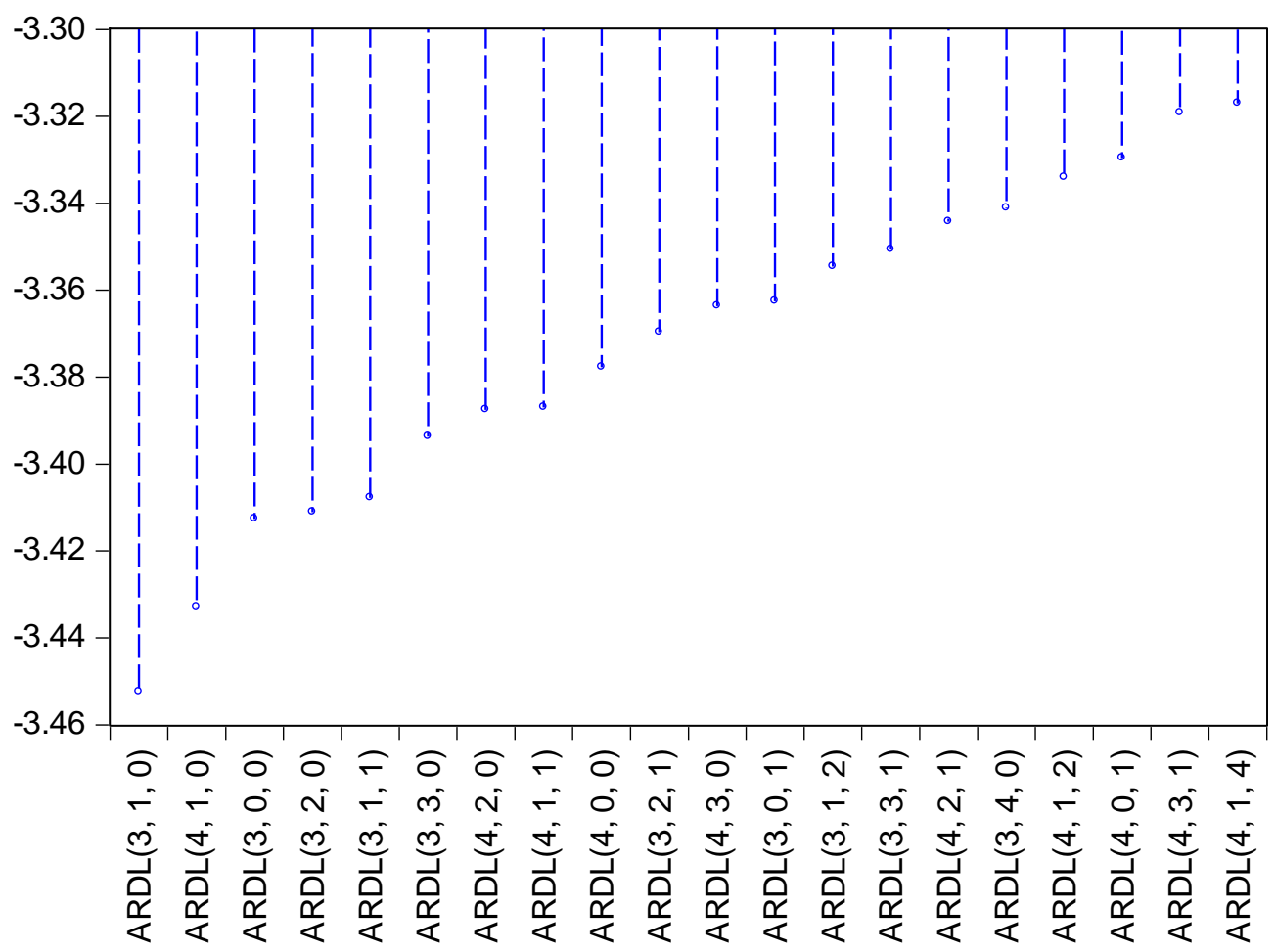

The starting step in the ARDL bounds test is nothing but the procedure of selecting optimal lag order for the estimation of the ARDL model, and VAR lag order selection criteria fulfills that. Among five criteria, three (majority) suggest lag 3 as optimal lag for conducting the ARDL model so that lag 3 is taken in this regard. After evaluating various models with lag 3 (the top-20 model with lag 3 are illustrated in Figure 2), the statistical software Eviews-9 confirms that ARDL $(3,2,0)$ model is the suitable model for this study. Table 3 includes the details of the ARDL $(3,2,0)$ model that is selected for this study, and the adjusted R-square, F-stat, and Durbin-Watson stat for this model are excellent- confirming the appropriateness of the model.

Table 3. Details of the Selected ARDL Model

Dependent Variable: LNCO2

\begin{tabular}{lcccc}
\hline Variable & Coefficient & Std. Error & t-Statistic & p-value \\
\hline LNCO2(-1) & 0.206241 & 0.156617 & 1.316849 & 0.1982 \\
LNCO2(-2) & -0.033713 & 0.161427 & -0.208845 & 0.8360 \\
LNCO2(-3) & -0.411993 & 0.156135 & -2.638689 & 0.0132 \\
LNPRGDP & -0.606853 & 0.558480 & -1.086616 & 0.2862
\end{tabular}


International Journal of Social Science and Economic Research

ISSN: 2455-8834

Volume:05, Issue:09 "September 2020"

\begin{tabular}{lllll} 
LNPRGDP(-1) & 0.552048 & 0.570645 & 0.967410 & 0.3413 \\
LNPRGDP(-2) & 0.568119 & 0.431324 & 1.317152 & 0.1981 \\
LNGI & 0.411524 & 0.204495 & 2.012394 & 0.0535 \\
C & -7.584612 & 1.499854 & -5.056901 & 0.0000 \\
@TREND & 0.038490 & 0.011446 & 3.362746 & 0.0022 \\
\hline R-squared & 0.995777 & F-statistic & 854.7256 \\
Adjusted R-squared & 0.994612 & Prob(F-statistic) & 0.000000 \\
& & Durbin-Watson stat & 1.961603 \\
\hline
\end{tabular}

(Source: Author's calculation)

Table 4. ARDL bounds test results

"Null Hypothesis: No long-run relationships exist"

\begin{tabular}{lll}
\hline Test Statistic & Value & $\mathrm{k}$ \\
\hline F-statistic & 9.970563 & 2 \\
\hline Critical Value Bounds & & \\
\hline Significance & $\mathrm{I}(0)$ Bound & $\mathrm{I}(1)$ Bound \\
$10 \%$ & 4.19 & 5.06 \\
$5 \%$ & 4.87 & 5.85 \\
$2.5 \%$ & 5.79 & 6.59 \\
$1 \%$ & 6.34 & 7.52 \\
\hline
\end{tabular}

(Source: Author's calculation)

The F-stat, calculated in this study, is 9.970- which is greater compare to the upper bound value of Pesaran (2001) table at a $1 \%$ level of significance (which is 7.52) and confirm the rejection of the null hypothesis of this test (see Table 4). Therefore, statistical evidence confirms that the variables LNCO2, LNPRGDP, and LNGI have a cointegrating relationship.

The elimination speed of the short-run (SR) divergence from the long-run (LR) equilibrating association, which is known as error correction speed, is 123.94 percent per year (Table 5). At this speed, the variables LNCO2, LNPRGDP, and LNGI will converge to their LR equilibrium per year from their SR discrepancies.

Table 5. Short-run and Long-run Results

Cointegrating Form

Variables

Coefficient

Std. Error

t-Statistic

Prob. 
International Journal of Social Science and Economic Research

ISSN: 2455-8834

Volume:05, Issue:09 "September 2020"

\begin{tabular}{lllll} 
D(LNCO2(-1)) & 0.445706 & 0.185664 & 2.400609 & 0.0230 \\
D(LNCO2(-2)) & 0.411993 & 0.156135 & 2.638689 & 0.0132 \\
D(LNPRGDP) & -0.606853 & 0.558480 & -1.086616 & 0.2862 \\
D(LNPRGDP(-1)) & -0.568119 & 0.431324 & -1.317152 & 0.1981 \\
D(LNGI) & 0.411524 & 0.204495 & 2.012394 & 0.0535 \\
D(@TREND()) & 0.038490 & 0.011446 & 3.362746 & 0.0022 \\
CointEq(-1) & -1.239465 & 0.224120 & -5.530355 & 0.0000 \\
\hline \multicolumn{1}{l}{ Long Run Coefficients } & & & & \\
\hline Variable & Coefficient & Std. Error & t-Statistic & Prob. \\
LNPRGDP & 0.414140 & 0.102568 & 4.037716 & 0.0004 \\
LNGI & 0.332017 & 0.172709 & 1.922413 & 0.0644 \\
C & -6.119260 & 0.973269 & -6.287324 & 0.0000 \\
@TREND & 0.031054 & 0.005793 & 5.360748 & 0.0000
\end{tabular}

(Source: Author's calculation)

The growth effect on $\mathrm{CO} 2$ emissions is found insignificant in the $\mathrm{SR}$, but significant at less than $1 \%$ in the LR (Table 5). In the LR, a $1 \%$ rise in economic growth will emit 0.414 percent CO2 in the atmosphere. Now, the variable which is in our interest, globalization, is significant both in the SR ( $\mathrm{p}=0.0535)$ and LR ( $\mathrm{p}=0.0644)$ at a $10 \%$ level of significance. Globalization-emissions elasticity is 0.4115 in the SR and 0.3320 in the LR. The LR elasticity is smaller than the SR elasticity- implying that globalization induced emissions will be reduced. This finding is consistent with theoretical understanding because theory suggests that globalization increases emissions at the initial phase of development. But, when the economy becomes more globalized and achieves matured economic development, the globalization induced emissions start to decline. Therefore, this finding delivers the message to the policymakers that it's unnecessary to take restriction policy to control globalization to save the environment, as globalization will not be harmful in the long-run. 
International Journal of Social Science and Economic Research

ISSN: $2455-8834$

Volume:05, Issue:09 "September 2020"

Figure 3. Illustration of Normality test results

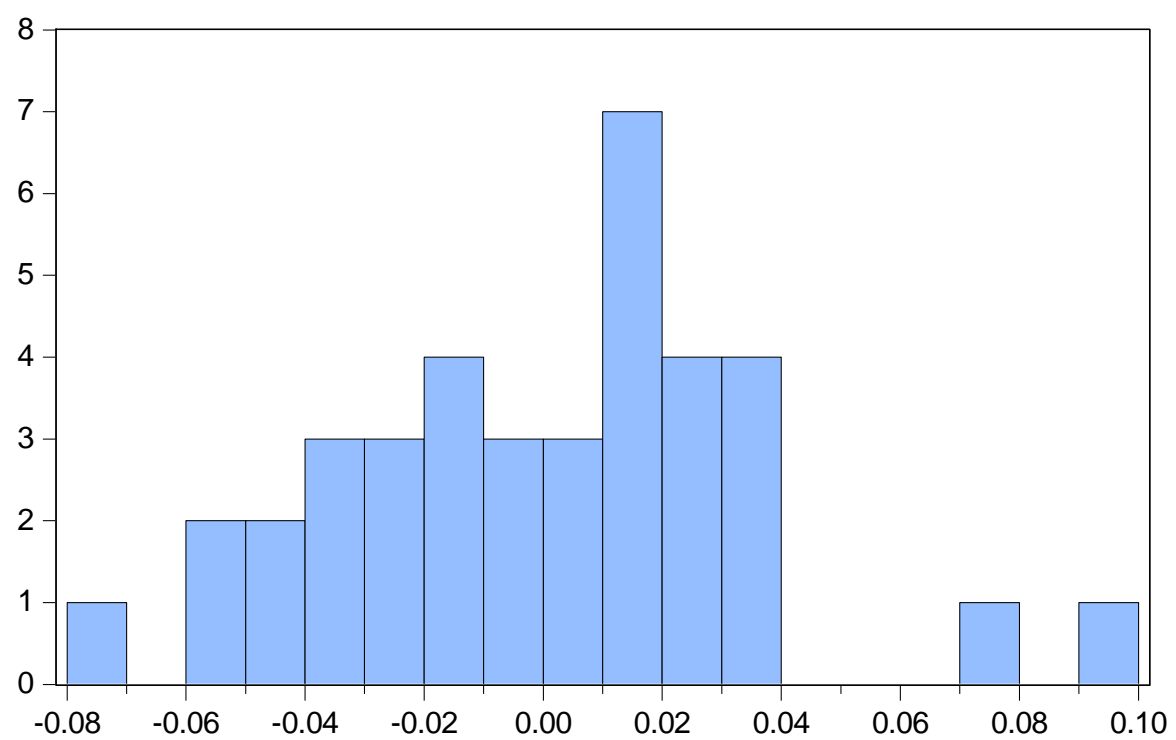

\begin{tabular}{|ll}
\hline \multicolumn{2}{|l}{ Series: Residuals } \\
Sample 1976 2013 \\
Observations 38 \\
Mean & $4.52 \mathrm{e}-16$ \\
Median & 0.001463 \\
Maximum & 0.090626 \\
Minimum & -0.071854 \\
Std. Dev. & 0.034624 \\
Skewness & 0.297889 \\
Kurtosis & 3.269307 \\
& \\
Jarque-Bera & 0.676838 \\
Probability & 0.712896 \\
\hline
\end{tabular}

Various diagnostic tests have been performed to make the estimated model more reliable, accurate, and consistent. The Jarque-Bera (JB) statistic is 0.6768 and the respective p-value is 0.7128 (much greater than 0.05 ), providing the confirmation of the non-rejection of the null hypothesis and proves that data used in this study were distributed normally (see Figure 3). Table 6 contains the details of the serial correlation test and heteroscedasticity test. In the serial correlation detection test, the p-value of the F-stat is 0.9672 and Chi-square-stat is 0.9542 , much higher than 0.05 , providing the statistical evidence against the alternative hypothesis and acceptance of the null hypothesis that no serial correlation in residuals. In the heteroscedasticity detection test, the $\mathrm{p}=0.8158$ for $\mathrm{F}$-stat, $\mathrm{p}=0.7644$, and $\mathrm{p}=0.9169$ for the two types of Chi-square stat. These values are much greater than the 0.05 , confirming that the null hypothesis is true and residuals are free from the heteroscedasticity problem.

Table 6. Serial Correlation and Heteroskedasticity test results

Breusch-Godfrey Serial Correlation LM Test

\begin{tabular}{llll}
\hline F-statistic & 0.033385 & Prob. F(2,27) & 0.9672 \\
Obs*R-squared & 0.093741 & Prob. Chi-Square(2) & 0.9542
\end{tabular}

Heteroskedasticity Test: Breusch-Pagan-Godfrey

\begin{tabular}{llll} 
F-statistic & 0.541118 & Prob. F(8,29) & 0.8158 \\
Obs*R-squared & 4.935645 & Prob. Chi-Square(8) & 0.7644 \\
Scaled explained SS & 3.261640 & Prob. Chi-Square(8) & 0.9169 \\
\hline
\end{tabular}

(Source: Author's calculation) 
Now, the details of the Ramsey RESET test have tabulated in Table 7. It is clear that the respective p-value of the F-stat is much greater than the 0.05 (actually it is 0.5814 ). This finding confirms the rejection of the alternative hypothesis and concludes that the model, used in this study, is specified correctly-there is no specification bias.

Table 7. Results of Ramsey RESET test

\section{Ramsey RESET Test}

\begin{tabular}{llll}
\hline & Value & $\mathrm{df}$ & Probability \\
\cline { 2 - 4 } t-statistic & 0.557866 & 28 & 0.5814 \\
F-statistic & 0.311214 & $(1,28)$ & 0.5814 \\
\hline
\end{tabular}

Finally, for the confirmation of the structural stability of the estimated coefficients of this study plot of the cumulative sum (CUSUM) and the square of the cumulative sum (CUSUM square) of the recursive residuals are illustrated in Figure-3 and Figure-4, respectively.

\section{Figure 3: Plot of CUSUM}

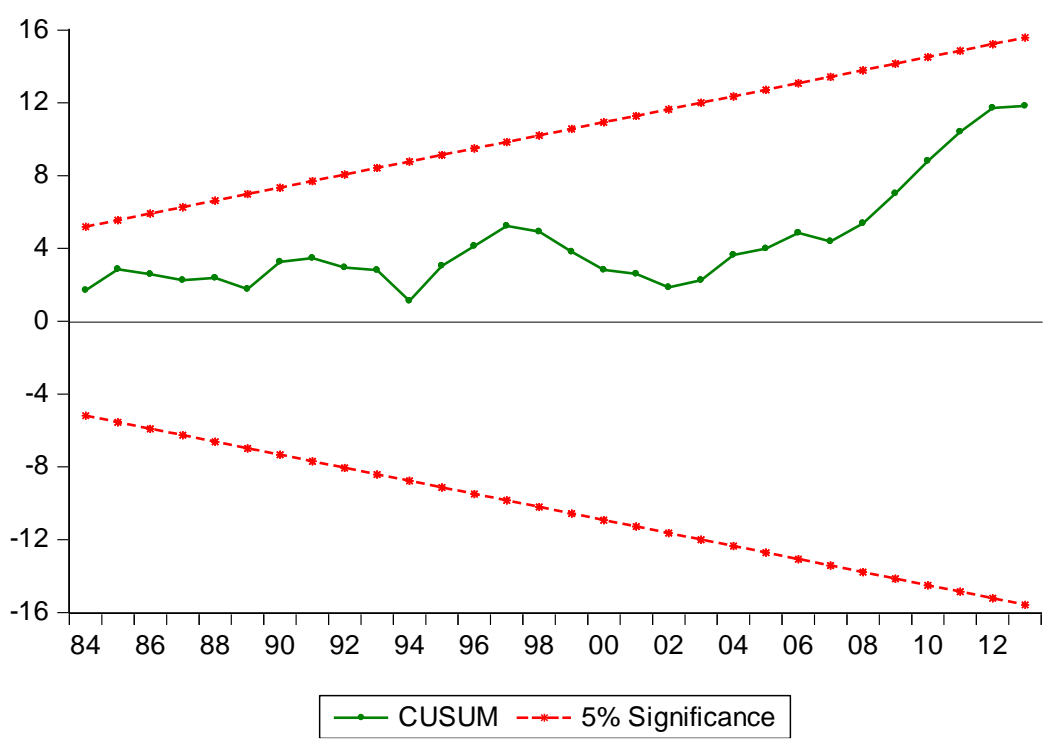




\section{Figure 4: Plot of CUSUM square}

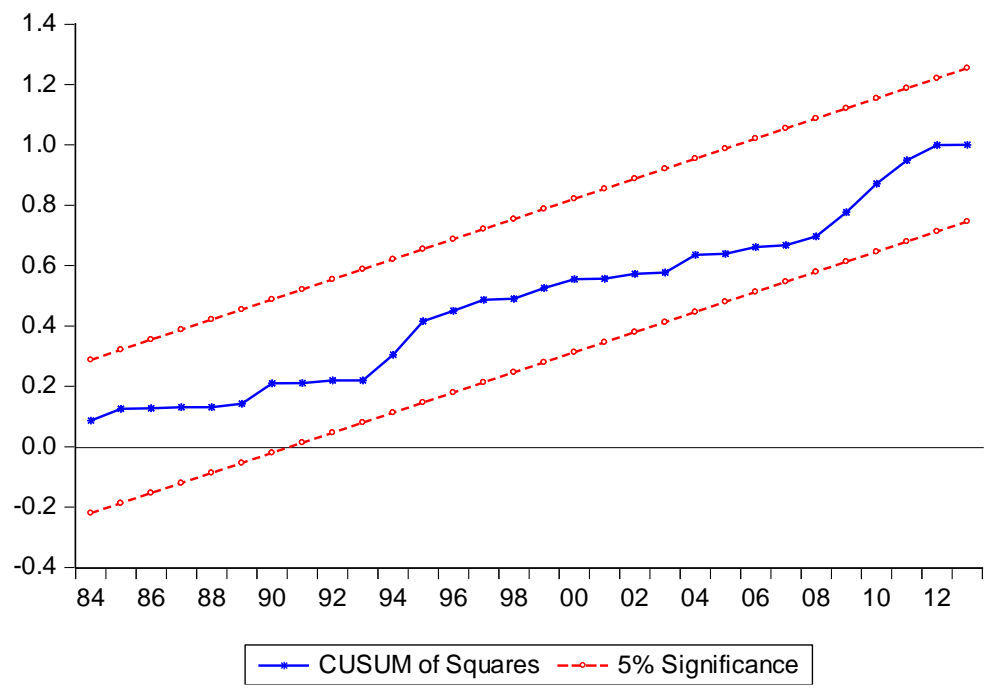

It is clear from the Figure-3 and Figure-4 that the plot of CUSUM and CUSUM of squares are within the bounds of the $5 \%$ significance level, which confirm that the estimated coefficients of this study are structurally stable and reliable. No structural break exists in the time frame used in this study.

\section{Conclusions}

Using the annual data of Bangladesh from 1973 to 2013, this study attempts to justify whether globalization degrades our environment or improve it. The results of this study reveal that globalization is significant both in the SR and LR at a $10 \%$ level of significance. Globalizationemissions elasticity is 0.4115 in the SR and 0.3320 in the LR. So, the LR elasticity is smaller than the SR elasticity- implying that globalization induced emissions will be declined. This finding is consistent with theoretical understanding because theory suggests that globalization increases emissions at the initial phase of development. But, when the economy becomes more globalized and achieves matured economic development, the globalization induced emissions will start to decline. Therefore, this finding delivers the message to the policymakers that it's unnecessary to take restriction policy to control globalization to save the environment, as the negative impact will be declined gradually in the long-run.

Acknowledgement: Thanks to IstihakRayhan for providing valuable and effective suggestions. 


\section{International Journal of Social Science and Economic Research}

ISSN: $2455-8834$

Volume:05, Issue:09 "September 2020"

\section{References}

AdebolaSolarin, S., Al-Mulali, U., \&Ozturk, I. (2017). Validating the environmental Kuznets curve hypothesis in India and China: The role of hydroelectricity consumption. Renewable and Sustainable Energy Reviews, 80, 1578-1587. https://doi.org/10.1016/j.rser.2017.07.028

Afzal, M. (2007). The Impact of Globalisation on Economic Growth of Pakistan. The Pakistan Development Review, 46, 723-734.

Akadiri, S. S., Lasisi, T. T., Uzuner, G., \&Akadiri, A. C. (2019). Examining the impact of globalization in the environmental Kuznets curve hypothesis: The case of tourist destination states. Environmental Science and Pollution Research, 26(12), 12605-12615. https://doi.org/10.1007/s11356-019-04722-0

Ang, J. B. (2007). CO2 emissions, energy consumption, and output in France. Energy Policy, 35(10), 4772-4778. https://doi.org/10.1016/j.enpol.2007.03.032

Daily Star, 2019. Bangladesh second fastest growing economy. Retrieved June 30, 2020 from: https://www.thedailystar.net/business/news/bangladesh-second-fastest-growing-economy-imf$\underline{1728289}$

Dickey, D. A., \& Fuller, W. A. (1979). Distribution of the Estimators for Autoregressive Time Series with a Unit Root. Journal of the American Statistical Association, 74(366), 427-431. https://doi.org/10.2307/2286348

Dickey, D. A., \& Fuller, W. A. (1981). Likelihood Ratio Statistics for Autoregressive Time Series with a Unit Root. Econometrica, 49(4), 1057-1072. https://doi.org/10.2307/1912517

Dreher, A. (2003). Does Globalization Affect Growth? (SSRN Scholarly Paper ID 348860). Social Science Research Network. https://papers.ssrn.com/abstract=348860

Dreher, A. (2006). Does globalization affect growth? Evidence from a new index of globalization. Applied Economics, 38(10), 1091-1110.

Farhani, S., Chaibi, A., \&Rault, C. (2014). CO2 emissions, output, energy consumption, and trade in Tunisia. Economic Modelling, 38(Supplement C), 426-434. https://doi.org/10.1016/j.econmod.2014.01.025

Gurgul, H., \&Lach, Ł. (2014). Globalization and economic growth: Evidence from two decades of transition in CEE. Economic Modelling, 36, 99-107. 


\section{International Journal of Social Science and Economic Research}

ISSN: $2455-8834$

Volume:05, Issue:09 "September 2020"

https://doi.org/10.1016/j.econmod.2013.09.022

Gygli, Savina, Florian Haelg, NiklasPotrafke and Jan-Egbert Sturm (2019): The KOF Globalisation Index - Revisited, Review of International Organizations, 14(3), 543-

574. https://doi.org/10.1007/s11558-019-09344-2

Khan, D., \&Ullah, A. (2019). Testing the relationship between globalization and carbon dioxide emissions in Pakistan: Does environmental Kuznets curve exist? Environmental Science and Pollution Research, 26(15), 15194-15208. https://doi.org/10.1007/s11356-019-04913-9

KOF Globalization Index, 2019. Retrieved from:

https://kof.ethz.ch/en/forecasts-and-indicators/indicators/kof-globalisation-index.html

Pao, H.-T., Yu, H.-C., \& Yang, Y.-H. (2011). Modeling the CO2 emissions, energy use, and economic growth in Russia. Energy, 36(8), 5094-5100. https://doi.org/10.1016/j.energy.2011.06.004

Pesaran, M. H., Shin, Y., \& Smith, R. J. (2001). Bounds testing approaches to the analysis of levelrelationships. Journal of Applied Econometrics, 16(3), 289-326. https://doi.org/10.1002/jae.616

Rafindadi, A. A., \& Usman, O. (2019). Globalization, energy use, and environmental degradation in South Africa: Startling empirical evidence from the Maki-cointegration test. Journal of Environmental Management, 244, 265-275. https://doi.org/10.1016/j.jenvman.2019.05.048

Rahman, M. M. (2020). Environmental degradation: The role of electricity consumption, economic growth and globalisation. Journal of Environmental Management, 253, 109742. https://doi.org/10.1016/j.jenvman.2019.109742

Rayhan, I., Akter, K., Islam, M. S., \& Hossain, M. A. (2018). Impact of Urbanization and Energy Consumption on CO2 Emissions in Bangladesh: An ARDL Bounds Test Approach. International Journal of Scientific and Engineering Research, 9(6), 838-843.

Rayhan, I., \& Islam, M. S. (2018). The role of Renewable Energy in the South Asian Countries in Reducing CO2 Emissions. THE JAHANGIRNAGAR ECONOMIC REVIEW, 29, 1-15.

Rayhan, I., \& Islam, M. S. (2015). Dynamic Causality between Urbanization and Environmental Degradation in Bangladesh: Evidence from ARDL Bounds testing approach. The Jahangirnagar Review, Part II: Social Sciences 2015, 105-117. 


\section{International Journal of Social Science and Economic Research}

ISSN: $2455-8834$

Volume:05, Issue:09 "September 2020"

Saboori, B., \&Sulaiman, J. (2013). CO2 emissions, energy consumption and economic growth in Association of Southeast Asian Nations (ASEAN) countries: A cointegration approach. Energy, 55(Supplement C), 813-822. https://doi.org/10.1016/j.energy.2013.04.038

Saboori, B., Sulaiman, J., \&Mohd, S. (2012). Economic growth and CO2 emissions in Malaysia: A cointegration analysis of the Environmental Kuznets Curve. Energy Policy, 51(Supplement C), 184-191. https://doi.org/10.1016/j.enpol.2012.08.065

Salahuddin, M., Gow, J., Ali, Md. I., Hossain, Md. R., Al-Azami, K. S., Akbar, D., \&Gedikli, A. (2019). Urbanization-globalization-CO2 emissions nexus revisited: Empirical evidence from South Africa. Heliyon, 5(6), e01974. https://doi.org/10.1016/j.heliyon.2019.e01974

Samimi, P., \&Jenatabadi, H. S. (2014). Globalization and Economic Growth: Empirical Evidence on the Role of Complementarities. PLOS ONE, 9(4), e87824. https://doi.org/10.1371/journal.pone.0087824

Saud, S., Chen, S., Haseeb, A., \&Sumayya. (2020). The role of financial development and globalization in the environment: Accounting ecological footprint indicators for selected onebelt-one-road initiative countries. Journal of Cleaner Production, 250, 119518. https://doi.org/10.1016/j.jclepro.2019.119518

Shahbaz, M., Mallick, H., Mahalik, M. K., \&Loganathan, N. (2015). Does globalization impede environmental quality in India? Ecological Indicators, 52, 379-393. https://doi.org/10.1016/j.ecolind.2014.12.025

Shahbaz, M., Shahzad, S. J. H., \&Mahalik, M. K. (2018). Is Globalization Detrimental to CO2 Emissions in Japan? New Threshold Analysis. Environmental Modeling \& Assessment, 23(5), 557-568. https://doi.org/10.1007/s10666-017-9584-0

Shahbaz, M., Solarin, S. A., \&Ozturk, I. (2016). Environmental Kuznets Curve hypothesis and the role of globalization in selected African countries. Ecological Indicators, 67, 623-636. https://doi.org/10.1016/j.ecolind.2016.03.024

Suki, N. M., Sharif, A., Afshan, S., \&Suki, N. M. (2020). Revisiting the Environmental Kuznets Curve in Malaysia: The role of globalization in sustainable environment. Journal of Cleaner Production, 264, 121669. https://doi.org/10.1016/j.jclepro.2020.121669

Ullah, F., Rauf, A., \&Rasool, N. (2013). Analyzing the Impact of Globalization on Economic Growth. ActaUniversitatisDanubius. Economica, 10(2). http://journals.univdanubius.ro/index.php/oeconomica/article/view/2199 
International Journal of Social Science and Economic Research

ISSN: 2455-8834

Volume:05, Issue:09 "September 2020"

World Development Indicator (WDI), 2020. World Bank Open Data, World Bank Group. Access at https://data.worldbank.org/country/BD

Ying, Y.-H., Chang, K., \& Lee, C.-H. (2014). The Impact of Globalization on Economic Growth. Journal for Economic Forecasting, 2, 25-34.

Zafar, M. W., Saud, S., \&Hou, F. (2019). The impact of globalization and financial development on environmental quality: Evidence from selected countries in the Organization for Economic Co-operation and Development (OECD). Environmental Science and Pollution Research, 26(13), 13246-13262. https://doi.org/10.1007/s11356-019-04761-7

Zahonogo, P. (2018). Globalization and Economic Growth in Developing Countries: Evidence from Sub-Saharan Africa. The International Trade Journal, 32(2), 189-208. https://doi.org/10.1080/08853908.2017.1333933 